\title{
sciendo
}

Research Article

(C) 2019 Egorychev et.al. This is an open access article licensed under the Creative Commons Attribution-NonCommercial-NoDerivs License (http://creativecommons.org/licenses/by-nc-nd/3.0/).

\section{Traditional Russian Family as a Basis for Sustainable Development of the State and Society}

\author{
Aleksander M. Egorychev ${ }^{1}$ \\ Lev V. Mardakhaev ${ }^{1}$ \\ Anna G. Akhtyan ${ }^{1}$ \\ Yanina V. Shimanovskaya ${ }^{1}$ \\ Rustam A. Archakov ${ }^{1}$ \\ Tamara E. Bykovskaya² \\ ${ }^{1}$ Russian State Social University, Moscow, Russia \\ ${ }^{2}$ Moscow Region State University, Moscow, Russia
}

Doi: 10.2478/ajis-2019-0028

\begin{abstract}
The relevance of the problem under examination is stemming from the present difficult situation with the basic institution of the Russian society, i.e. the Russian family. Modern researchers explore the issues related to the present and future of the Russian family institution as a basis for sustainable development of the state and society. They analyze the condition of the present-day Russian family and reveal the reasons of its crisis. The authors of this research firmly uphold the position that only revival of traditional meanings and values of the Russian family will allow to keep its high status in the society and to foster sustainable development of the Russian state and society. This research is aimed at identifying and validating the factors and conditions that contribute to the revival of the traditional foundations of the Russian family, and to the sustainable development of the Russian state and society as a whole. The main approaches to the study of this problem were culturological and socio-historical, which allow to solve the pursued goals and objectives. The paper presents the analysis of the current socio-political situation in Russia, identifies and validates the main aspects and causes of the existing harsh reality of the Russian institution of family, discloses and identifies factors and conditions essential for sustainable development of the country. The materials of this research have practical value for researchers and specialists dealing with problems of the Russian family and challenges of sustainable development of the Russian society.
\end{abstract}

Keywords: Russian state, society, sustainable development, traditional Russian family, values, traditions, Russian culture, mentality of the people

\section{Introduction}

The urgency of the problem examined by this research is attributable to many aspects and factors. First, the foundation of any state and society is the family, which is the defining condition of sustainable development of the country, preservation of its national historical meanings and values, social norms and traditions, everything that constitutes the mentality of the people's culture, represents the national identity of a particular country. We can confidently say that the family, the 
well-being of which determines the future of the state and the society, is the basic factor (social institution) of Russia's national security, sustainable development and welfare. Secondly, the modern state family policy of Russia began to emerge in the 1990s, when the realization came that the new time demands new approaches to its implementation. The Decree of the President of the Russian Federation "On the Main Directions of State Family Policy" dated May 14, 1996 N 712, heralded the beginning of a new era in the implementation of the state family policy in the country (Decree of the President of the Russian Federation "On the Main Directions of the State Family Policy", 1996). However, as evidenced by the actual practice, the condition of the modern Russian family is alarming and requires immediate actions and revision of the state family policy in Russia. Thirdly, the institution of the family functions and develops in organic unity with other state and public social institutions, and is determined by the state policy, which implies an in-depth analysis of the condition and functioning of all social institutions of Russian society, including the state social policy for their development.

It should be noted that the Government of Russia headed by its President closely monitors all processes related to the functioning and development of the institution of the Russian family. Thus, in his message to the Federal Assembly of the Russian Federation (2019), President Vladimir Putin highlighted the importance of building the family policy for the sustainable development of Russian society: "For our society, for the multi-ethnic people, it is the family, the birth of children, the continuation of the family, respect for older generations that have been and remain a powerful moral framework. We have been and we will continue doing everything to solidify family values. This is a matter of our future. A common goal for the state, civil society, religious organizations, political parties and the mass media" (Putin's message to the Federal Assembly, 2019).

Today it is hard to overestimate the importance the statement by Vladimir Putin. Modern Russian realities are very complex and contradictory, and despite all other internal and external affairs, the country stubbornly paves its way to the future. However, for the first time in the last decade, Russia has seen a negative trend: death rate has begun to exceed the birth rate. So according to the Russian Federal Statistics Service, in 2018 in Russia there is an excess of deaths over births by a factor of 1.2. There are regions where this figure is twice as high (Demographic policy: ratio and statistics of fertility and mortality in Russia, 2019). This trend speaks volumes and, above all, that today family policy implemented in the Russian Federation proves to be inefficient, which may have serious implications for the future of Russia.

\section{Literature Review}

As many Russian researchers point out, the current state of the family in the Russian Federation, from the point of view of national security, appears to be quite threatening and poses risks to the sustainable development of the country, which highlights the need to revise the state family policy (Klintsova, 2018, Minushkina \& Ponkratova, 2018; Ryabenko, 2014).

M.N. Klintsova (2018), noting the crisis state of the Russian family, writes that "in modern Russian society there is a reduction in the number of families and simplification of their composition, limitation of the number of intrafamily and kinship ties, democratization of the principles of family life, increasing autonomy of generations, broken intergenerational ties and continuity of generations" (Klintsova, 2018).

K.E. Minushkina and E.A. Ponkratova (2018) write that "the decline in living standards, unemployment, low wages, deteriorating health of the population make it impossible for the families to fully implement their basic functions" (Minushkina \& Ponkratova, 2018, pp. 73-74).

V. Ryabenko (2014) has undertaken a thorough analysis of the condition of the Russian family, noted the dramatic situation with the Russian family, which consists in the fact that the material and psychological difficulties experienced by the family led to the emergence of completely new problems related to upbringing, which previously were considered atypical. Insecure parents lose their authority and cease to be a role model for their children. The children no longer turn to their parents for advice and help so often as before, considering them incapable of surviving in the new circumstances. Further, the author concludes that "the national interests of Russia require urgent measures for social support of the family, which is the main constituent unit of the society" 
(Ryabenko, 2014).

Z.A. Zhapuev (2013) makes a direct link between development of the Russian society and the functioning of the family institution, and writes that this problem is extremely acute for Russian society, which social immunity in the context of institutional transformation is rapidly decreasing, thereby threatening the national security of Russia.

Summarizing all the judgements made by modern researchers about the present-day Russian family and society, we can say that the lack of clear goals and basic strategy for the development of Russia, which should determine the ideology and policy of its national priorities, gives rise to a crisis in the functioning and development of the family institution and sustainable development of the Russian state and society in general.

\section{Research Methodological Framework}

This research is analytical in nature. The general methodology of this research was the theory and statements of Russian philosophers and thinkers about the meanings and values of Russian culture, the logic of historical development of the Russian state and society. The research objective is to identify and validate the crisis situation with the Russian society and the family institution and to determine possible ways for its overcoming. The research objectives: to identify the main factors that create risks and threats to the functioning and development of the Russian society and the family institution; identify the role of systemic ideas constituting the basis for implementation of the current state family policy; to validate a need for revival of the traditional Russian family; to identify the principles of revival of traditional meanings and values of Russian family; to define the role of family traditions in the development of Russian family and sustainable development of the society. This research employed the methods of socio-philosophical analysis, comparing and contrasting (Fedotova \& Chigisheva, 2015), aggregation and abstraction of research materials and forecasting the sustainable development of the Russian society and the family institution.

\section{Findings and Discussion}

A thorough analysis of both the scientific literature and the current political and socio-cultural situation in Russia related to the institution of the Russian family has revealed that today we are witnessing negative trends affecting the sustainable development of the Russian state and society:

1. Decrease in the quality and standards of living of many Russian families, which leads to the inability of most families to create favourable conditions for upbringing and socialization of the younger generation.

Starting from 2014 the real disposable cash income of the population has continued to decline for four years in a row. According to the Russian Federal Statistics Service, $55 \%$ of the population receives monthly wages below RUB 25,000, and $23 \%$ below RUB 15,000. Every sixth officially employed Russian worker of employable age has an income lower than the minimum subsistence level, taking into account that the received income is spent not only on their own selves, but also on their families (Incomes and living standards in Russia and possible changes in year 2018, 2018).

2. Increased number of dysfunctional families, even with a high income, which creates the risks associated with their upbringing and educational capabilities and the development of family spiritual and moral values.

The number of single-parent families in Russia has risen to $30 \%$ over recent years. At present, 6.2 million families in the country are incomplete: in Russia there are $5.6 \mathrm{mln}$. single mothers and 634.5 thousand single fathers. More than half of the parents who do not live with their children periodically evade the payment of alimony, and every third parent does not pay the alimony at all, every 7 th child under 18 years of age in Russia is raised in a single-parent family. Most of the single-parent families are single mothers with children (94\%) (Statistics of dysfunctional families in Russia, 2019).

3. The processes disrupting the lives of Russian families are aggravating: the instability of marriages increases, the number of divorces grows, and the traditional forms of its 
functioning, the established moral and ethical norms and traditional intrafamily relationships are destroyed. Every second "basic unit of society" falls apart in the country. The majority of divorced couples are aged between 18 and 35 years, and in $68 \%$ of cases the divorce is filed for by women (Statistics of marriages and divorces in Russia, 2018).

4. There is a growing social phenomenon, such as "detachment between parents and children", lack of attention and interest on both sides, mutual misunderstanding and emotional isolation, which impedes successful implementation by the family of its functions.

Russian society, in general, has become more prone to conflicts. Irritation, high fatigue, indifference and lack of desire for spiritual intimacy with family members, poor family culture - these are the components of the interaction between parents and children.

5. The destruction of historically established traditional relationship between a man and a woman is observed, which leads to disturbance of the feminine nature, a woman's true purpose as a mother, and at the same time men lose moral responsibility for the fate of their women and families, etc.

All over the world, including Russia, there is a targeted systemic disorientation of human society in the matters concerning both the conventional morality and ethical standards, and the system of gender-sexual relations. "The purpose of this technique is to impose the so-called modern democratic norms of behavior by manipulating and popularizing the feminist movement. At the same time, homosexuality and lesbianism are promoted" (Destruction of the family. Destruction of the traditional family. Destruction of the family institution, 2019). Such targeted social policy results in the destruction of the foundations of the traditional institution of family and marriage.

The negative trends discussed above may be supplemented with the following: the causes of homelessness and abandonment of children, children left without parental care, including social orphanhood, still remain; the age of onset of sexual activity is decreasing, which has an impact on the productive health of moms to be and on the formation of moral values of the younger generation; the trend towards an increase in the average age of marriage is on the rise, while the general and reproductive health of women of childbearing age is worsening, with a negative impact on population growth. The most important thing is that the role of the state in the social upbringing and socialization of children, teenagers and young people is diminishing, which, in general, affects both the social health of the younger generation and the social well-being of the Russian society as a whole and its sustainable development.

The protection of the Russian family, its support and development is a complex problem. This fact implies the necessity to introduce special corrections into the state family policy, which should be implemented in synergy with all other policy directions, and with reliance on the below principles:

Firstly, preservation and development of the institution of the Russian family should be the highest priority of the state social policy. The Russian family should be considered as a factor of national security of the Russian state and society, the sustainable development of which depends on successful solution to national security problems.

Secondly, all social institutions and entities of the Russian state and society (the system of education, health care, all ministries, political parties, religious and public organizations, etc.), mass media should be involved in the solution of the problems of preservation and development of the Russian family and their activities should be subordinated to the ideology of preservation of the Russian traditional family values.

Thirdly, all activities within the framework of the state policy for the preservation and development of the Russian family should be targeted, systemic, comprehensive and well managed.

In modern Russia, there are plenty of documents aimed at supporting and developing the Russian family. One of them is the Concept of State Family Policy in the Russian Federation until 2025 (2014) (hereinafter the Concept). In general, the Concept referred to above, represents a consistent idea of and a view on the problem of the Russian family: "The state family policy is an integral system of principles, tasks and priority measures aimed at supporting, strengthening and protecting the family as a fundamental pillar of the Russian society, preserving traditional family values, raising the role of the family in the life of the society, increasing the authority of parenthood 
in the family and society, preventing and overcoming family dysfunction, improving conditions and quality of life of families" (The Concept of State Family Policy in the Russian Federation until 2025, 2014). Expected results of the Concept implementation: "The result of the implementation of this Concept will be the range of measures finalized by 2025 aimed at creating conditions conducive to serving the interests and meeting the needs of families, increasing their economic independence, their role in the personal self-fulfillment, the upbringing of new generations, strengthening the prestige of marriage and the family lifestyle" (The Concept of State Family Policy in the Russian Federation until 2025, 2014). Everything is consistent, right and impersonal.

Four and a half years have passed since the adoption of this Concept (2014), however, the quoted words still remain wonderful wishes. This means, first of all, that:

1. The existing implementation of the state family policy in Russia, despite the declarative statement about its systemacity and comprehensiveness, is neither systemic nor comprehensive, which undermines efficiency of measures, leads to a continuing crisis of the family institution and disruption of sustainability of the Russian society.

2. Systemic ideas concerning solution to the problems of the Russian family, adopted for the implementation within the management system of the state family policy, lack scientific validity at the high level, and fail to meet the historical meanings and values of the Russian culture. Systemic ideas underlying implementation of the current state family policy (concepts, strategies, decrees, programs, plans, codes, etc.) should: have a clear scientific basis accounting for the socio-cultural dynamics in the country and the multiethnic way of life of the Russian people, etc.; pursue the goals and meanings of the Russian culture, reflect the traditional family meanings and values of the Russian family.

Strengthening and protection of the Russian family today is possible only through the historical meanings and values which for centuries were created by the Russian people, carefully maintained, used for family preservation and development, and passed from generation to generation. The traditional values of the Russian family are the historical legacy of the past generations invested into the future of Russia, the key to its prosperity, welfare and sustainable development.

3. Today in our country, propaganda and popularization of traditional meanings and values of the Russian family have no clear concept and lack targeted systemic activities with the participation of all state and social institutions and entities of the Russian Federation.

Today, Russian mass media do not have clear state standards and guidelines related to the development of Russian society and people with a high level of spiritual culture. The mass media activities are driven, to a large extent, by their trivial interest in profit. The traditional meanings and values of Russian culture (service to the Motherland, patriotism, duty, spirituality, virtue, morality, etc.), including traditional family values (marriage, multi-child family, marital fidelity, responsibility towards the family, etc.) are almost completely disregarded. The wide variety of behaviour and communication patterns, including sexual relationships that are constantly being demonstrated to young people cannot be a proper model for them in terms of creation of their own families.

All of the above suggests that upbringing of the Russian younger generation (children, teenagers, youth) through the meanings and values of Russian culture, the nurturing in them of basic culture of family relationships, raising their awareness of importance of creating a traditional family requires from the Russian state and society a tailored strategy and program, its all-national discussion and approval, targeted and systemic implementation.

Systemic and targeted actions taken by all institutes and entities of the Russian state and society to promote and popularize the traditional meanings and values of the Russian family will allow to completely transform the social status of the Russian family, to raise public prestige of motherhood and fatherhood, to develop in young generation a solid motivation to have the multichild family, and hence, to boost sustainable development to the Russian state and society.

\subsection{Revival of the traditional Russian family}

The revival of the traditional Russian family is to a large extent determined by the relevant principles underpinning development and implementation of the state family policy that are dictated 
by: the goals and objectives of the state family policy, the multi-ethnic composition of the country, its regional specificities, the current socio-cultural situation (demographic, economic, socio-cultural, religious and other), etc. Let's summarize and give a brief overview of the basic principles:

- Principle of family sovereignty. It assumes its high level of independence in the organization of its life (choice of a place of residence, economy, upbringing of children, leisure, etc.). Excessive state guardianship in the form of an increasingly complex system of juvenile justice does not contribute to the revival and strengthening of traditional family culture in Russian society;

- Principle of family responsibility implies a reasonable and fair distribution of family responsibilities (functions) between spouses and all family members with account of their age, gender, health, interests, etc. The overall responsibility for the material, spiritual and moral well-being and development of the family is borne by its head, i.e. a man (a husband), while a woman (a wife) acts as the host and preserver of the hearth. State family policy measures should be aimed at providing delicate assistance and support to the family to ensure its social health, functioning and development (economic, sociocultural, physical, spiritual and moral, etc.);

- Principle of socio-cultural continuity. It implies the preservation and development of the social norms, meanings and traditional values historically developed by the Russian people, which for many centuries helped to preserve the institution of the family, their further transmission to the younger generation (love, kindness and fidelity, mutual understanding and respect, respect for parents and elders, responsibility for close people, universal assistance and mutual help, etc.), as well as: high responsibility of a man (husband, father) for his family, relatives and friends, taking over the solution of all problems and complex family situations; full assumption by a wife of the main function of a mother, personal self-fulfillment through the birth and upbringing of children, creation of a family comfort and atmosphere of trust, taking on all household chores. State family policy should be expressed in the support to traditional organizational forms of the Russian family, which will ensure its development and stability;

- Principle of social importance of the family. It is intended to raise the status of the institution of the Russian family in the country, to elevate its role as an institution of upbringing and socialization of the younger generation, the guardian of traditional meanings, values and norms of life of the Russian people. The state, acting as a defender of the Russian family, should develop and implement a system of measures to promote its advancement into the center of the overall social policy of the Russian state, its transformation into a driving force of the social development of Russia. The family becomes a criterion and indicator of the state social policy in general and the efficiency of its implementation;

- Principle of balance of rights and responsibilities of a child in the family. It implies the approval in the Russian family environment of norms of behavior, interaction and activity of children in accordance with the traditional form of organization of life of the Russian family (full and equal participation of a child in all family affairs, economic and leisure activities). The state's participation in securing the rights and obligations of a child in the Russian family should unobtrusively guarantee this balance;

- Principle of preservation of individual family space. It implies respect for the freedom of each Russian family to develop their own family traditions (communication and interaction, means and methods of upbringing, organization of economy and leisure activities, etc.) that do not contradict the Russian legislation. Maintaining their confidentiality on the part of all state and public entities. Various measures implemented as a part of the state family policy (legal, socio-cultural, financial and economic, educational, etc.) are designed to promote its free choice in terms of self-fulfillment and self-development.

\subsection{Traditions as the basis for social health of the Russian family}

The social, spiritual and moral health of the Russian family and society as a whole can be judged 
by its traditions. Family traditions are the primary vehicle for promoting norms, meanings, spiritual and socio-cultural values that determine both social health of the family and welfare of the society. The role of family traditions in the Russian family was originally:

- to create strong ties between the members of a large multigenerational and multi-child family, and create a sense of unity, stability and reliability among its members;

- to cultivate a high sense of responsibility towards the family in each of its members, to include everyone in the daily care for each other, to motivate them to serve their family selflessly.

All members of the traditional Russian family through the family traditions were included in its life that allowed to create and develop the family sociocultural environment conducive to natural evolvement of socially significant personal qualities of the younger generation, and to lay the groundwork for its socialization and national consciousness.

Family traditions in the Russian society have been evolving for many centuries, have been carefully maintained and passed on from generation to generation. Centuries have passed and family traditions have developed into a genetic socio-cultural matrix essential not only for the survival of the Russian state and society, but also for its successful development, preservation of national and civil identification of the Russian people.

Each Russian family had a single socio-cultural genetic matrix, based on which it built its unique family tradition, which, nevertheless, always reflected the common semantic values and spiritual and moral foundations inherent in all Russian people. Traditional Russian family, filled with established meanings, values, traditions, Orthodox faith, pursued a single goal which consisted in development of a person who would correspond to the social ideals and norms of the Russian community, and would serve for its preservation and development.

\section{Conclusion}

Today, being in the most challenging conditions of world aggression and instability, Russia needs national unity, cohesion and togetherness more than ever in order to maintain its sustainable development. The heart of this national unity should be, as in all the past historical times, the traditional Russian family that generates and transmits through the younger generation the highest values of the Russian state and society, such as love and loyalty to their family and homeland, patriotism and desire to serve the Fatherland, make it strong and beautiful. It is the traditional Russian family that acts as a basic social institution ensuring sustainability of the Russian state and society.

\section{References}

Decree of the President of the Russian Federation "On the Main Directions of the State Family Policy" dated May 14, 1996 No 712 (1996). Retrieved from http://www.consultant.ru/cons/cgi/online.cgi?req $=$ doc\&base $=E X P \& n=255452 \# 05896429070231859$ on April 5, 2019.

Demographic policy: ratio and statistics of fertility and mortality in Russia (2019). Visual analytics of the modern world. Retrieved from https://infografics.ru/all/rozhdaemost-i-smertnost-v-rossii/ on April 9, 2019.

Destruction of the family. Destruction of the traditional family. Destruction of the family institution (2019). Retrieved from http://www.i-kiss.ru/rubrika/razrushenie semi on April 6, 2019.

Fedotova O., \& Chigisheva O. (2015). Comparative Analysis: Methodological Optics in the Ideological Context. In: Comparative sciences: interdisciplinary approaches. Series: International perspectives on education and society, 26, 57-81.

Incomes and living standards in Russia and possible changes in year 2018 (2018). Retrieved from http://wikibusiness.ru/doxody-i-uroven-zhizni-v-rossii-i-perspektivy-ix-izmeneniya-v-2018-g/ on April 8, 2019.

Klintsova, M.N. (2018). Modern Russian family: the main trends. Retrieved from https://cyberleninka.ru/article/n/sovremennaya-rossiyskaya-semya-osnovnye-trendy on May 20, 2019.

Minushkina, K.E., \& Ponkratova, E.A. (2018). Social problems of Russian families in modern socio-economic conditions. Young Scientist, 34, 73-74.

Putin's message to the Federal Assembly on February 20, 2019 (2019). Retrieved from https://tehnowar.ru/98598-poslanie-putina-federalnomu-sobraniju-20-fevralja-2019-g-video-polnyjtekst.html on April 8, 2019. 
Ryabenko V. (2014). Current state of the family institution. Retrieved from https://magref.ru/sovremennoesostoyanie-instituta-semi/ on May 26, 2019.

Statistics of dysfunctional families in Russia (2019). Retrieved from https://sibyurist.ru/nedejstvitelnostsdelok/statistika-neblagopoluchnyh-semej-v-rossii-2019 on March 10, 2019.

Statistics of marriages and divorces in Russia (2018). Retrieved from http://semeinoe-pravo.net/statistikabrakov-i-razvodov-v-rossii/ on April 5, 2019.

The Concept of State Family Policy in the Russian Federation until 2025 (2014). Approved by the Decree of the Government of the Russian Federation on August 25, 2014. Retrieved from https://rg.ru/2014/08/29/semya-site-dok.html on April 8, 2019.

Zhapuev, Z.A. (2013). Modern family as a factor of sustainable development of Russian society. Power, 21(1), 99-101. 